\title{
Research of the management of moral education and higher vocational students
}

\author{
ZHOU Miaoquan ${ }^{1, a}$ \\ ${ }^{1}$ Student Affairs, Guangxi Teachers College, Guangxi 532200,China \\ azhoumiaoquan@yeah.net
}

Keywords: higher vocational colleges; Moral education; management

\begin{abstract}
In recent years, along with our country economy and social development of the surge in demand for diversity, cultivating high-quality applied talents of higher vocational education to long-term development. But due to some of society such as via the Internet is not straight atmosphere affects today's teenagers, make a small part of the higher vocational college students lacking in ideological and moral aspects, although only a few, but for today's society is the devil. Explore vocational students education administration work, earnestly analyze the present situation of higher vocational students' moral education to higher vocational students can find out dock with the method of moral education and management, to achieve the aim of talent cultivation in higher vocational colleges, promote rapid and healthy development of higher vocational moral education management is very necessary.
\end{abstract}

\section{Introduction}

Forward of sex is the moral law of development and the unity of the twists, college students' moral self development law generally through the multiple collision $\rightarrow$ values clarification $\rightarrow$ new mould construction $\rightarrow$ overall improve several stages. Due to the social environment changes and the particularity of education patterns and subject, to college students' ideological and moral education has brought certain difficulty. The ideological and moral education work of college students must grasp the pulse of The Times, improve college students' ideological and moral qualities. Moral education needs to renew the idea, there are quite a number of people in college students' different levels of moral problems, many students' vocational ideal floating, professional learning motivation, students' ideological understanding, career orientation and overall good values in life, the moral education work is a systems engineering, students' moral education of higher vocational colleges should actively explore new ways of moral education work of college students under the new situation, new way, efforts to create a new situation of the moral education work.

\section{Problems in moral education in higher vocational colleges is analyzed}

\section{1 weak sense of responsibility}

In recent years, college students' morality absence, crime phenomenon is gradually serious, investigate its reason, because of the weak and the social sense of responsibility for itself. Under the impact of the cruel talent competition in the market today, some students due to want to break through, will all his mind in professional knowledge learning and the cultivation of professional quality, focus on personal ability to ascend, and gradually to ignore the political theory of learning, makes some lack of morality, and society; Some students persecution by some bad information of network, the distortion of ideology and morality, the negative cases on the network as a learning example, in the end its consequences; Part of students in higher vocational colleges of benign competition, due to rein, and distorts the psychological abnormality, losing morality, machiavellian; And part of the student to know ahead of time social fierce competition society, on the values and orientation is too real, "money-oriented" ideological interference was supposed to clean the ideological, cynical, profit-seeking abandon righteousness of grow in quantity, with the center of my individualism and hedonism thought gradually increased. 


\section{2 lack of social public morality}

In nowadays higher vocational colleges, we can see some couples basic cotton backslapping, embraced and kissed, regardless of the surroundings behavior too intimate and disturb the people around; Dozen rice, not waiting in line when you pick up the money, don't take good care of public health, especially the part of students themselves don't study hard, for the teacher's discipline and some excesses, not respecting teachers and support staff; Disturb others rest in the dormitory, don't speak hygiene, speak loudly in the library classrooms and other places of learning, eat, etc; Public toilets don't flush, don't take good care of public school facilities, trample on the lawn, in the study room, dining room seat, comparing ourselves with others blindly, the heart, nothing to do; Don't on the bus offer their seats to sick child initiative; And a few vocational college students lack of honesty, whether in love or career is very sloppy and, worse binge drinking on campus last due punishment in violation of public security administration law and so on.

\section{3 the contemporary college students' morality}

1 , with the development of science and technology, the Internet this double-edged sword has immeasurable role in student life, via the Internet contains violence, pornography, gambling and superstitions, decadent and backward culture and harmful information on the severe corrosion to the hearts of young students; 2 . Some college students lack of honesty, whether in love or career is very sloppy and even fraud. Part of students down, doing nothing all the bad thoughts and actions, the author deeply worried and upset, this is before we are education workers, especially the ideological and political education workers of a long-term and urgent task.

\section{2.the lack of ideological and ethical analysis and solution}

Modern new Confucian ethical thoughts and thoughts of Marxism ethics, promote the development of Marxist ethical thoughts and prosperity, and to college students' moral choices left a space to think.

\section{1 the different psychological quality.}

Compared with the ordinary university students, either they have no sense of balance and ignored, or discrimination against each other psychological, or have a rebellious attitude, naughty, not disciplined, are a typical manifestation of their immaturity. Psychological quality is different, require student moral education work in higher vocational colleges must be tailored to the interest of the students ideological characteristics.

\section{2 students' different levels.}

At present, various kinds of subjective and objective factors that determines the level of vocational students are uneven, enter oneself for an examination of higher vocational college is generally can not meet the scores of high school students in common colleges and universities and education, vocational and technical school "counterpart". Lower levels of stress from their heart inferiority, depressed, volatile enrolled after thoughts. Students' different levels, demands students moral education and ideological and political work in higher vocational colleges can eliminate the students' inferiority complex, firm the confidence of the finish. Devote herself should motivate them to face self, learning, better complete their studies.

\section{3 social awareness of different.}

Society have some prejudice in higher vocational colleges, is not only conducive to the development of higher vocational education, is unfavorable to the cultivation of the students self-confidence. Due to the social recognition is not high, insufficient understanding, often to their own or understanding of their own biases. Social cognition is different, the moral education work in higher vocational colleges students can make students have a correct understanding of higher vocational firm of choice. Vocational students focus on learning and mastery of professional knowledge and skills, influence factors of the ideological and moral qualities of higher vocational students are mainly the influence of market economy, on the one hand, is advantageous to the 
enterprise competition in the market economy system, equality, competition, etc. The formation of new morals and strengthening, promoting the advancement of social morality; On the other hand, the blindness of market economy itself, spontaneity and interest principle, the principle of equivalent exchange and bring about many negative impacts, on the general mood of society and students' ideological and moral.

\section{The docking of the management of moral education and students}

For the contemporary college students in higher vocational colleges, should to penetrate moral education to the student management, so as to promote students' moral quality in the life of medium.

\section{1 create a good learning environment}

Will school inspirational motto stands in marked place, to remind the student to carry on the cultivation of their moral and behavior; In corridor, publicity column, billboards, to beautify the design with motivational statements, warning motto to anywhere at any time reminding students and education, create a positive atmosphere; Build and play a role of graphic information center and campus network information education, optimize network and audio-visual environment purification; In the classroom, dining hall and other places of public learning, living and activities with a few signs to remind students take good care of public facilities, to the life quality promotion education; To develop campus culture activities regularly at the same time, regularly held in the campus lectures, positive activities, such as fundraising, rubbish, etc, undertake to the student moral education through the campus culture festival activities.

\section{2 construction of curriculum system of science}

To undertake to the student moral education management, necessary step is to consider in the curriculum, in specialized courses at the same time to carry out some of the moral education courses in order to perfect the moral quality of college students in higher vocational colleges. Worth reference some of the courses are: 1, the labor education and labor education students as a elective course Settings, each student must participate in several times within the term of labor, and labor effect should be brought into the final appraisal; 2, quality education, for different students in different types of the corresponding moral education, the students according to different types, such as academic classification, according to the characteristics of different targeted education. 3 , the social practice course. Will regularly organize students, actively participate in various health outside of school, is the student out of the campus, feel the positive energy of society, improve the moral accomplishment, strengthen students' sense of responsibility and innovation spirit.

\section{3 manage the rewards and punishment system}

To student's thought morals results on a regular basis between school leaders meeting to discuss and formulate effective rewards and punishment system, form the public opinion atmosphere. Ideological and moral evaluation to adjust the thought and behavior of college students has a certain guidance and correction, with actual case of the students make clear what should advocate the students, against what, pursue what, what restraint; Yes, no anything; What is the good, and what is ugly, so as to correctly guide students moral level of accomplishment, advocacy and maintaining moral behavior, revealed and criticized some do not conform to the requirements of the social and normative words and deeds, improve the students' self awareness, self education and self management ability and level. Do good to some excellent spiritual and material aspects of the double rewards to students, thus to guide the students in the right direction development; For students moral thoughts walked curved road, have to be education even if, not nominated as a cautionary tale of education to guide other students, when necessary, must carry on the punishment, let the student know the school for students management is not muddle along, so that the students inner fear. 


\section{Conclusion}

Through the above analysis, we can see that the moral quality of college students there are still some missing, we should to penetrate moral education to the student management, is the student through the various aspects in teaching and life to feel the necessity of the moral and the students' moral ideas from various aspects lead to the correct path.

\section{Acknowledgement}

Guangxi Education Science "Twelfth Five-Year" plan for 2011 college students in Guangxi Research Program funded the research results. Topic Number: $2011 Z Z 022$

\section{References}

[1] Zhou Xianjin. Environmental moral education in colleges and universities [M]. Changsha: hunan people's publishing house, 2005:62-68.

[2] KouXiang. Theory of experiential [J]. Journal of moral education of colleges and universities school party construction and ideological education, 2010 (3) : 67-68.

[3] Li hui. The demand for higher vocational students of unit of choose and employ persons the status of the investigation [J]. Journal of education and profession, 2010 (7) : 42-43.

[4] Li Guxiang Wang Wen. Professional ethics education [M]. Kunming: yunnan university press, 2006:245-247. - Po to mesh 